Airborne Spread of Foot-andMouth Disease - Model Intercomparison

J. Gloster, A. Jones, A. Redington, L. Burgin, J. $H$. Sorensen, R. Turner, M. Dillon, P. Hullinger, M. Simpson, P. Astrup, G. Garner, P. Stewart, $R$. D'Amours, $R$. Sellers, and D. Paton

September 17, 2008

Veterinary Journal 
This document was prepared as an account of work sponsored by an agency of the United States government. Neither the United States government nor Lawrence Livermore National Security, LLC, nor any of their employees makes any warranty, expressed or implied, or assumes any legal liability or responsibility for the accuracy, completeness, or usefulness of any information, apparatus, product, or process disclosed, or represents that its use would not infringe privately owned rights. Reference herein to any specific commercial product, process, or service by trade name, trademark, manufacturer, or otherwise does not necessarily constitute or imply its endorsement, recommendation, or favoring by the United States government or Lawrence Livermore National Security, LLC. The views and opinions of authors expressed herein do not necessarily state or reflect those of the United States government or Lawrence Livermore National Security, LLC, and shall not be used for advertising or product endorsement purposes. 


\section{Airborne spread of foot-and-mouth disease - model intercomparison}

John Gloster $^{\mathrm{a}}{ }^{\text {, Andrew Jones }}{ }^{\mathrm{b}}$, Alison Redington ${ }^{\mathrm{b}}$, Laura Burgin ${ }^{\mathrm{b}}$, Jens H. Sørensen ${ }^{\mathrm{c}}$, Richard Turner ${ }^{\mathrm{d}}$, Michael Dillon ${ }^{\mathrm{e}}$, Pam Hullinger ${ }^{\mathrm{e}}$, Matthew Simpson ${ }^{\mathrm{e}}$, Poul Astrup ${ }^{\mathrm{f}}$, Graeme Garner ${ }^{\mathrm{g}}$, Paul Stewart ${ }^{\mathrm{h}}$, Réal D’Amours ${ }^{\mathrm{i}}$, Robert Sellers ${ }^{\mathrm{j}}$, David Paton ${ }^{\mathrm{k}}$

${ }^{a}$ Met Office, currently based at the Institute for Animal Health, Pirbright, Woking, Surrey GU24 0NF, UK

${ }^{\mathrm{b}}$ Met Office, FitzRoy Road, Exeter, Devon EX1 3PB, UK

${ }^{\mathrm{c}}$ Danish Meteorological Institute (DMI), Lyngbyvej 100, DK-2100 Copenhagen, Denmark

${ }^{\mathrm{d}}$ NIWA, Private Bag 14-901 Kilbirnie, Wellington, New Zealand

${ }^{\mathrm{e}}$ Lawrence Livermore National Laboratory, P.O. Box 808, L-103, Livermore, CA 94551, USA

${ }^{\mathrm{f}}$ Risø National Laboratory, Technical University of Denmark - DTU, Building 118, P.O. Box 49, DK-4000 Roskilde, Denmark

${ }^{\mathrm{g}}$ Office of the Chief Veterinary Officer, Department of Agriculture, Fisheries and Forestry. GPO Box 858, Canberra, ACT, 2601, Australia

${ }^{\mathrm{h}}$ National Meteorological and Oceanographic Centre, Bureau of Meteorology. GPO Box 1289, Melbourne, Victoria 3001, Australia

${ }^{i}$ Environment Canada, Canadian Meteorological Centre, 2121 North Service Road, Dorval, Quebec, Canada, H9P iJ3

${ }^{j}$ Retired. 4 Pewley Way, Guildford, Surrey, GU1 3PY, UK

${ }^{\mathrm{k}}$ Institute for Animal Health, Pirbright Laboratory, Ash Road, Pirbright, Woking, Surrey GU24 0NF, UK

\footnotetext{
${ }^{1}$ Corresponding author. Tel.:+44 1483231023
}

E-mail address: john.gloster@bbsrc.ac.uk 
Version 1.0 Submitted to Veterinary Journal

Input from LB, RS, MD, PH, RA, JS

3 September 2008

\section{Abstract}

Foot-and-mouth disease is a highly infectious vesicular disease of cloven-hoofed animals caused by foot-and-mouth disease virus. It spreads by direct contact between animals, by animal products (milk, meat and semen), by mechanical transfer on people or fomites and by the airborne route - with the relative importance of each mechanism depending on the particular outbreak characteristics. Over the years a number of workers have developed or adapted atmospheric dispersion models to assess the risk of foot-and-mouth disease virus spread through the air. Six of these models were compared at a workshop hosted by the Institute for Animal Health/Met Office during 2008. A number of key issues emerged from the workshop and subsequent modelling work: 1) in general all of the models predicted similar directions for "at risk" livestock with much of the remaining differences strongly related to differences in the meteorological data used;2) determination of an accurate sequence of events is highly important, especially if the meteorological conditions vary substantially during the virus emission period; and 3) differences in assumptions made about virus release, environmental fate, and subsequent infection can substantially modify the size and location of the downwind risk area. Close relationships have now been established between participants, which in the event of an outbreak of disease could be readily activated to supply advice or modelling support.

\subsection{Introduction}

Over the years, a variety of models, including mathematical models and agent based spatial stochastic models have been developed to provide support to a wide range of decision makers, including those responsible for controlling and eradicating outbreaks of foot-and-mouth disease (FMD). Depending on their complexity, these models can either investigate a variety of outbreak scenarios by combining a full range of disease parameters or modelling in detail one particular aspect of spread.

The Animal Health Quadrilateral Group (Quads) established a working group on epidemiology and modelling (EpiTeam) in March 2005 at the request of the Chief 
Version 1.0 Submitted to Veterinary Journal

Input from LB, RS, MD, PH, RA, JS

3 September 2008

Veterinary Officers of Australia, Canada, New Zealand and the USA. A key focus of the EpiTeam's work programme has been an international FMD epidemiological modelling comparison study, which is being used as a testing and verification tool for the various FMD simulation models developed by individual countries to assist in FMD policy development and preparedness. Dubé et al. (2007) describe a comparison of the results from three such models. The models compared were AusSpread (Garner and Beckett, 2005; Beckett and Garner, 2007), Interspread Plus (Sanson, 1993; Stevenson et al. 2003), NAADSM (Schoenbaum and Disney 2003).

In a separate but related initiative, the authors have sought to compare models used internationally to estimate one aspect of FMD spread (airborne spread). Since the early 1980's atmospheric dispersion models have been used to help identify livestock at risk from FMD virus released into the atmosphere from infected animals (Gloster et al., 1981). These models have been developed and are available for use in a number of countries including the United Kingdom, Denmark, Australia, New Zealand, Canada and United States of America.

During 2005 it was recognised by a number of those involved in modelling airborne disease transmission that they had never all met to discuss their approach to modelling a disease outbreak and to compare their models. A preliminary intercomparison involving the UK Met Office, Danish Meteorological Institute and Risø Institute (Denmark) was held in September 2005. The outputs from both the UK and Danish models were compared under operational conditions for several hypothetical outbreaks of FMD. One of the main conclusions from the intercomparison was the need to develop a closer co-operation between all of those known to have responsibilities for modelling airborne transmission of FMD. To start this process it was decided to organise a workshop at the Institute for Animal Health (IAH). This paper describes the workshop which was held on 7 and 8 February 2008 and subsequent model intercomparisons.

\subsection{Methodology}

\subsection{Objectives}


As a first step IAH/Met Office contacted representatives of the countries who were known to have a specific responsibility of providing advice to their governments on airborne spread of FMD. After discussion it was agreed to hold a workshop in the UK with the following objectives:

- To foster closer working relationships between groups of scientists who were likely to be involved in their countries' emergency response to an outbreak of FMD.

- To understand the different modelling approaches to the airborne spread of FMD virus.

- To see if the models made similar predictions on the likelihood of airborne spread.

To achieve these objects it was decided that prior to the workshop all participants would model the same outbreak of FMD and provide those responsible for controlling and eradicating disease with advice concerning which livestock in the area provided was at risk from airborne virus. The advice format was unspecified, but must be readily assimilated by those unfamiliar with the technicalities of atmospheric dispersion modelling. In addition, the participants were expected to be prepared to describe their models and outputs, highlight relevant issues and identify areas for future collaboration.

At the workshop, it was recognised that an additional model intercomparison was warranted to evaluate relative model performance, once uncertainty in input parameters (namely virus emission) were removed.

\subsection{Modelling scenario}

The 1967 Hampshire, UK outbreak of FMD was selected by IAH/Met Office as being suitable for the workshop; the outbreak had been investigated previously by Sellers and Forman (1973) and Gloster et al. (1981) and they concluded that up to sixteen of the farms could have become infected by airborne virus from either Fareham Abattoir 
Version 1.0 Submitted to Veterinary Journal

Input from LB, RS, MD, PH, RA, JS

3 September 2008

or other premises, twelve most likely from the abattoir. Figure 1 gives the locations of the infected premises, together with the locations of the major conurbations in the area, the coastline and an area of high ground (Portsdown Hill - shaded area) to the east of Fareham Abattoir (outbreak no. 9).

On 6 January 1967 FMD was confirmed in cattle at Southwick, Hampshire (outbreak no.1). Lesions were recent in the two affected animals. On the following day two further outbreaks of disease were confirmed, in cattle, a few kilometres to the west of the original case. On 8 January recent disease was confirmed in a large number of pigs $^{1}$ in a swill fed herd near Havant. Infection was considered to have been introduced to this outbreak in waste food which could have contained imported meat scraps. A further outbreak was confirmed in pigs on 9 January at Fareham Abattoir (Outbreak no. 9). It was found that 44 pigs from the swill-fed herd had been moved to the abattoir on 29 December and 65 pigs on 3 January; normally animals were brought in to the abattoir and slaughtered within 24 hours. However, no slaughtering took place from 1300 on Saturday 31 December to 0500 on Monday 2 January and from 1300 on Saturday 7 January to 0500 on Monday 9 January and during these periods live animals were kept at the abattoir. As a result infection could have been introduced and circulated in the abattoir from 29 December. The $29^{\text {th }}$ and final infected premise in the outbreak was declared on 3 February.

\subsection{Provision and interpretation of input data}

For the workshop it was decided to keep the data as simple as possible, but provide sufficient data for the modellers to run their models relatively easily and highlight major issues. The information provided consisted of:

- A written scenario, as recorded by the Divisional Veterinary Officer (provided by Dr R F Sellers). The information included the location of the infected animals, numbers and species of affected/total stock, numbers and

\footnotetext{
${ }^{1}$ Research workers over the years have established that pigs are by far the most prolific emitters of airborne virus (reviewed by Gloster et al. submitted); for certain virus strains this may be as much as 100 times that for cattle or sheep. With regard to infection, cattle with a greater sampling volume are more likely to become infected than either sheep or pigs (reviewed by Sellers and Gloster, 2008).
} 
ages of lesions (i.e. the basic details that may be available during the early stages of a disease outbreak).

- Hourly meteorological data recorded at the Met Office's observation station at Thorney Island (Figure 1 - TI) and synoptic weather charts for the relevant period extracted from the Met Office, UK archive.

- Topographical data extracted from the Ordnance Survey Panorama data set and gridded to $100 \mathrm{~m}$ over the outbreak area.

- Location of 144 cattle premises in the immediate vicinity of the infected area.

In providing their guidance to disease controllers, participants were encouraged to freely interpret the data provided, especially when it came to re-creating the unfolding disease scenario and then for all to adopt a standard scenario. In the second round of modelling intercomparison a standard emission scenario provided to participants (Table 1) and was calculated by assuming a mean daily emission profile produced by considering all of the experimental work involving type $\mathrm{O}$ virus (Gloster et al. submitted for publication) and two periods of virus emission from animals at the abattoir (one assuming some virus release between 31 December and 2 January and the second from 6 to 9 January). It is appreciated that this scenario is only one possible interpretation of events and that virus may/may not have been present and been emitted in aerosol form from the abattoir at any time from 29 December. Modellers were invited to produce their output for one day (9 January) and for the total emission period (29 December to 9 January).

Appreciating that some of the models required numerically derived meteorological data and others observations, participants were free to select the most appropriate source of meteorological data.

In view of the conclusions drawn by Sellers and Forman (1973) participants were asked to concentrate their efforts on modelling the potential spread of FMD virus from Fareham Abattoir.

\subsection{Models}


Version 1.0 Submitted to Veterinary Journal

Input from LB, RS, MD, PH, RA, JS

3 September 2008

Six model systems were compared at the workshop and in subsequent modelling runs:

NAME - UK Met Office (Jones et al. 2007);

VetMet Danish Meteorological Institute, Danish Veterinary and Food Administration, Danish Institute for Food and Veterinary Research, Risø National Laboratory for Sustainable Energy - Technical University of Denmark (Sørensen et al., 2007; Mikkelsen et al. 1997; Sørensen et al. 2000; Sørensen et al. 2001).

PDEMS - NIWA, New Zealand (Turner and Clarkson, 2006; Scire et al. 2002a; Scire et al. 2002b; Sanson 1993).

AIWM - Australian Department of Agriculture, Fisheries and Forestry and the Bureau of Meteorology (Garner et al. 2005; Hess et al. 2008; Draxler and Hess 1998). MLCD - Canadian Meteorological Centre (D'Amours and Malo, 2004; Flesch et al. 2002).

NARAC - National Atmospheric Release Advisory Center. USA (Nasstrom et al. 2007; Leone et al. 2005; Skamarock et al. 2005.; Leone et al.; Grell and Dèvènyi, 2002; Kalnay, et al. 1996).

Whilst there are differences in detail, all of the models were similar in overall design, consisting of two inputs (virus emission and meteorology), the model itself and graphical outputs. Readers requiring further details about specific models should refer to the references given. Whilst the models are used to predict the likely spread of FMD virus they have much wider applications and are routinely used operationally, by the respsective authorities, to model nuclear, chemical, biological and other particular releases. As part of this work they have taken part in a number of model evaluations and harmonisation activities (e.g. http://www.harmo.org; Van Dop et al. 1998).

Virus emission - A virus emission profile is constructed as a function of time using a combination of clinical data collected from the field (species of animals involved, numbers and ages of lesions as a function of time), together with aerosol data derived from laboratory observations. A review of virus emission data is given by Gloster et al. (accepted for publication). 
Version 1.0 Submitted to Veterinary Journal

Input from LB, RS, MD, PH, RA, JS

3 September 2008

Virus emissions from infected animals are modelled as a cloud of infectious aerosol, with each aerosol containing a proportion of the total virus released. This aerosol cloud is subsequently transported downwind and diluted by mixing with the ambient atmosphere. A number of models include dry and wet deposition processes and effects of biological decay. At short ranges, some of the models have the capability of measuring short-period concentration fluctuations and the effects of small-scale terrain on dispersion

Meteorology - Meteorological data, representative of the atmospheric conditions at the infected premises and downwind, was provided either from the nearest weather observing station or from numerical weather prediction models. In the latter case observational data from a wide range of input sources are assimilated into a single description of the atmosphere at a number of grid boxes at different vertical levels in the atmosphere. The horizontal resolution of the boxes varies considerably from a few to tens of kilometres square and from a few to tens of different levels in the atmosphere.

Graphical output - The output fields of the atmospheric dispersion models are typically ground-level values of total time-integrated virus concentration, maximum hourly value within a 24 hour period and/or a time series of 6-hour average concentrations. The potential downwind extent of infections are either estimated using the cattle threshold of $0.06 \mathrm{TCID}_{50} / \mathrm{m}^{3}$ (24 hr average air concentration) suggested by Sørensen and Jensen (1996) or expressed as areas of relative risk. The cattle threshold has been derived from some laboratory work, where measured dosages of virus were given to cattle and the resultant infection monitored. Model output is generally presented graphically using a G.I.S. A number of the models have the capability of providing a concentration time series at selected locations e.g. particularly significant at risk livestock holdings.

\subsection{Results}

\subsection{Emission estimates}


Version 1.0 Submitted to Veterinary Journal

Input from LB, RS, MD, PH, RA, JS

3 September 2008

There were considerable variations in the virus emission values adopted by modellers as a function of clinical signs of disease (Table 2a). Virus emissions were assumed to have occurred over either a four or five day period starting on either the day that first clinical disease was evident (D1) or the day before this (D-1). Most assumed that maximum emission occurred on D1 or D2, but one modeller had used D2 and D3. Estimates of peak virus emissions also varied from a lower value of $6 \times 10^{5}$ $\mathrm{TCID}_{50} / 24$ hours to an upper estimate of $1 \times 10^{7} \mathrm{TCID}_{50} / 24$ hours. Given these differences in estimates of daily emissions it is not surprising that the overall production of virus (Table $2 b$ ) also showed considerable variation; on a number of days there were two orders of magnitude difference between the values chosen by the modellers. With one exception, modellers limited virus emissions to the times estimated from clinical examination of the pigs at the abattoir had found lesions (two pigs with four day old lesions (DOL), four with three DOL and four with two DOL). The UK (along with other modellers) had recognised that virus emission may have occurred earlier, but rather than attempting to construct a possible emission pattern, they had assumed a standard daily release for the whole period $\left(8 \times 10^{5} \mathrm{TCID}_{50} / 24\right.$ hours), allowing a relative comparison between the days to be made.

\subsection{Meteorology}

Half of the models (NAME, VetMet, PDEMS) were run using the observational data provided and half (AIWM, MLCD and NARAC) used numerically derived model data. An hourly wind rose analysis for Thorney Island is given at Figure 2; the analysis is divided into two periods (29 December to 2 January and 3 to 9 January). The figure shows the direction from which the wind has blown as a percentage of the total time. For the early period the wind was from the north west, through west to south and the second predominantly from west through north to east.

Four of the models (NAME, VetMet, PDEMS and NARAC) included the effect of local topography at a horizontal resolution of a few hundred metres, whilst the remainder had not; most of the models can include a local topography module but participants had elected not to use it for this case study. 
Version 1.0 Submitted to Veterinary Journal

Input from LB, RS, MD, PH, RA, JS

3 September 2008

\subsection{Areas at risk}

\subsubsection{Initial model runs}

There was good agreement between models concerning the main directions at risk of spread from Fareham Abattoir, all of which correlated closely with the Thorney Island wind data. An example of the modelled output (PDEMS), for the period 3 to 9 January, is given at Figure 3.

A number of minor differences in the direction at risk were identified by comparing the different model results. These differences were shown to be primarily related to the choice of input weather data. For example, a sensitivity study performed by the NARAC modelling group showed that there were significant differences in the wind direction between Thorney Island observations and the output of a numerical prediction (NWP) model for the morning of 7 January, 1967 (during other time periods, the observed and modelled wind direction generally agreed. On this day, the NWP output indicated a smooth, counter-clockwise wind shift from the northwest to the northeast. In contrast, the observations indicate an abrupt change from a southerly wind to a north-westerly wind at 15:00 and a north-easterly wind at 6:00. This difference resulted in the presence, or absence, of potential risk areas to the northeast of Fareham Abattoir.

Whilst the direction of the area at risk was in general agreement there were substantial differences in the predicted distance from the source that cattle were at risk. Again this was not surprising bearing in mind the substantial differences in virus emission values adopted by modellers (Table $2 \mathrm{~b}$ ). If the strict criteria of $0.06 \mathrm{TCID}_{50} / \mathrm{m}^{3}(24 \mathrm{hr}$ average air concentration) suggested by Sørensen and Jensen (1996) were to be adopted then only those cattle within the immediate vicinity of Fareham Abattoir would have been at risk. However, most modellers adopted a cautious approach to predicting the area at risk. Some suggested that cattle out to $4 \mathrm{~km}$ were at risk (PDEMS). Others, acknowledging the uncertainties in determining an accurate virus emission estimate, provided areas of relative risk (NAME, AIWM and NARAC). For example the NAME modellers offered the following advice "to inspect all cattle farms 
Version 1.0 Submitted to Veterinary Journal

Input from LB, RS, MD, PH, RA, JS

3 September 2008

within the medium and high risk areas, starting with the largest units first and impose restrictions on all livestock movements in and out of the low, medium and high risk areas". NARAC modellers provided a sensitivity study illustrating that while infections were most likely near the abattoir, a "worst case" emission scenario, based on the largest amount of FMD virus emitted as aerosol, measured in the laboratory, would result in infections exceeding $30 \mathrm{~km}$ of Fareham Abattoir.

\subsubsection{Standard emission}

The results from all models, using the same emission data, for the 9 January are given at Figure 4 and for the period 31 December to 9 January at Figure 5. As was to be expected, all of the models now produced closer agreement than in the initial runs. For example the models identified that the direction of greatest risk, for 9 January, being the sector between south east through south to south west from Fareham Abattoir; this sector is in close agreement with the wind directions recorded at Thorney Island where 21 out of 24 hours had winds between $340^{\circ}$ and $10^{\circ}$ with speeds between 2 and 10 knots.

For the full period (Figure 5), the models were again in good agreement, with the only significant differences being related to the input meteorology (particularly noticeable in the northwest sector); unfortunately it was not feasible, for practical reasons, to use the same meteorological inputs in all models.

Two final comparisons between the models were made. Firstly, each modeller provided values for the total 24 hour integrated concentrations along the major axis of the plume at 1, 5, 10, 15 and $20 \mathrm{~km}$ for 9 January (Table 3). Whilst there are some differences most estimates are within one order of magnitude; this could easily be accounted for by the different assumptions within the model with respect to the rate at which surface material diffuses upward in the atmosphere and choice of input weather data. Secondly, the outbreaks suggested by Sellers and Forman (1973) as being potentially infected by airborne virus emitted from Fareham Abattoir were compared with the modelled output. Participants were asked to divided their output into four categories (high, medium, low and no risk). The locations of the affected farms were 
superimposed on these outputs. Table 4 presents the results. All of the outbreaks identified by Sellers and Forman (1973) were assessed as at risk by the models. In general there was very good agreement between the models for premises close to the source, but this agreement decreased with distance, as expected, as differences between chosen input weather data become more pronounced. MLCD modellers assessed the risk for all of the cattle premises in the immediate area (144 farms); seven farms out of 40, assessed as high risk, subsequently became infected. Four out of 40 , assessed as medium risk became infected and one out of 58, assessed as low became infected.

\subsection{Discussion}

The modelling intercomparison has brought together for the first time a number of key modellers from around the world. As a result each participant has a clearer understanding of the capabilities of each modelling system and a dialogue has commenced creating an environment for close co-operation if, or when, future FMD outbreaks occur.

A number of key issues have emerged from the work. Overall, it is reassuring to note that given almost identical input data all of the models predicted similar directions for "at risk livestock" that correlate closely with the wind direction. After the virus emission rates were synchronised the remaining differences appear to be closely linked to differences in how four-dimensional atmospheric conditions were inferred from a limited set of measurement data ${ }^{2}$.

Determination of the sequence of events in the field is seen as vital if high quality guidance concerning the potential of airborne disease spread is to be provided. Input data that is vague or partial will make the assessment of airborne risk more qualitative and potentially misleading or wrong. Whilst it is appreciated that in a real outbreak additional information beyond that provided to the workshop participants may be available. However, it is the experience from those of the group who have had to

\footnotetext{
${ }^{2}$ Since 1967 there have been considerable improvements in the quality of numerically derived meteorological data. As a result it is likely that differences between observations and derived data in a current outbreak will be less than in this exercise.
} 
Version 1.0 Submitted to Veterinary Journal

Input from LB, RS, MD, PH, RA, JS

3 September 2008

model actual outbreaks that this is not always the case and further effort should be targeted to efficiently streamlining the collection of critical information.

For the initial modelling runs, each participant assumed a different relationship between clinical disease and virus production. Differences in quantity released and its timing can have a major impact on determining the direction of risk from a given release point and how far the risk extends downwind. To help inform this process for the future, a review has been undertaken of the experimental work where measurements of FMDV in aerosol form have been made. In the review all of the published data have been harmonised for pigs, cattle and sheep as a function of virus strain and a number of suggestions made concerning how best to use the data to model new outbreaks of disease (Gloster et al., accepted for publication in Veterinary Journal).

A number of modellers estimate the distance downwind for possible infection assuming a threshold level of infection based on 24-hour average concentrations of $0.06 \mathrm{TCID}_{50} / \mathrm{m}^{3}$ for cattle and $1.0 \mathrm{TCID}_{50} / \mathrm{m}^{3}$ for sheep as suggested by Sørensen and Jensen (1996). It was agreed that these values are useful indictors but it is recognised that they are far from definitive. All of the laboratory work relating to dose required to initiate infection has recently been reviewed by Sellers and Gloster (2008). The review showed that there is considerable variation in the amount of virus required to initiate infection. How these laboratory based experiments relate to the field is not clear, especially when laboratory work has, for good practical reasons, been performed with statistically low numbers of livestock. This is in direct contrast to the situation in the field where the numbers are likely to be considerably greater. In the light of these uncertainties the output from NAME has now been modified to only show relative levels of risk (high, medium, low and none). This type of information when combined with other epidemiological evidence concerning disease spread, whilst appearing less precise, is believed by the modellers in the UK to provide the right level of support to those responsible for disease control; veterinary surveillance can first be targeted to the high risk area and then if resources allow to the lower risk areas. 
Version 1.0 Submitted to Veterinary Journal

Input from LB, RS, MD, PH, RA, JS

3 September 2008

Experience from modelling past outbreaks has shown that not all cattle which are exposed to theoretically similar amounts of airborne virus become infected. Whether this is a feature of the quality of the input data, capability of the model, natural fluctuations of particles within a virus plume, local topography and differences in physiology of the susceptible animals is hard to determine. Even if the models are perfect in their predictions it is important to remember that these are predictions of infection risk and are therefore subject to stochastic variation. From a disease control viewpoint it would be helpful to prioritise those units which are at greatest risk. Due to time constraints this aspect was not studied in detail at the workshop. However, the Hampshire 1967 outbreak has recently been studied by Schley et al. (accepted for publication by Interface, Journal of the Royal Society) and it was concluded that the size of the unit together with the predicted particle load was sufficient to be able to identify infected farms with high sensitivity and specificity; this finding has also been substantiated by other workers (Hess et al. 2008).

The intercomparison also showed that a number of the models can include such factors as biological decay (a decrease in viability due to unfavourable atmospheric factors such as low relative humidity or high temperature) and wet and dry deposition $^{3}$. Recent work, both for this workshop (NARAC) and independently published (Hess et al. 2008) using sensitivity analyses suggests that including these processes can significantly affect the downwind extent of the hazard plume and their accurate characterization is necessary to provide a quantitative assessment of airborne FMD spread. The workshop participants recognized that if these effects are to be included, then additional experimental work is required. This should be focussed on gaining a deeper understanding of the precise composition of the aerosol emitted and its survival once it is in the atmosphere. For example is airborne virus emitted as discrete very small particles each containing a small quantity of virus or in larger particles containing enough virus to induce infection? The way that these are modelled and the associated risk area calculated are likely to be very different. Until this shortfall in understanding has been addressed care should be taken when including biological or decay factors in risk assessment.

\footnotetext{
${ }^{3}$ Limited laboratory work suggests that FMD virus can be stable in aerosols at a relative humidity above $55-60 \%$ and at temperatures below $33^{\circ} \mathrm{C}$ (Donaldson, 1972; Donaldson and Ferris 1974).
} 
Version 1.0 Submitted to Veterinary Journal

Input from LB, RS, MD, PH, RA, JS

3 September 2008

The Hampshire 1967 outbreak occurred in the winter months when the effects of local sea breezes were likely to be small. However, if it had occurred in the summer then these could have seriously influenced the area at risk. Also, if there were cold atmospherically stable nights, typically associated with winter and spring months, the local flows around Portsdown Hill could have influenced where airborne virus was transported and increased the virus concentration near the surface. Weather prediction models, especially at coarse grid scale resolutions, experience difficulties in resolving small scale meteorological features; in extreme cases the difference between modelled and actual wind direction can be $180^{\circ}$. In contrast, observations are helpful in resolving local airflows, but only if they are in the right location and of sufficient density to accurately map the local wind patterns;; even within an area of good observational coverage, sources of observations may be tens or more kilometres apart. Consequently, considerable care must be taken when initiating a model run to ensure that the most appropriate meteorology for the area of concern is used and use the model results within the limitations of accuracy dictated by the combination of model and input data.

Finally, in light of the wide variety of modelling choices used and fundamental uncertainties in the input data, the workshop participants agreed to the need for a "best-practices" modelling guide that would include a set of well-defined, standardized modelling products that would help answer common questions facing disease controllers.

\subsection{Acknowledgements}

The authors readily acknowledge the contributions made to the intercomparison by Leonard Mansley, Søren Alexandersen, Torben Mikklesen, Alistair Manning and David Schley. Thanks are also given to Defra for funding project SE4025.

Richard Turner wishes to thank Graham Mackereth of Biosecurity New Zealand, who provided a virus emission profile for PDEMS, and to the Royal Society of New 
Version 1.0 Submitted to Veterinary Journal

Input from LB, RS, MD, PH, RA, JS

3 September 2008

Zealand who provided financial support to attend the intercomparison meeting through it's International Science and Technology Linkages fund.

Graeme Garner wishes to acknowledge the contributions of Dale Hess of CSIRO Marine and Atmospheric Research and Xue Yang from the Bureau of Meteorology.

Pam Hullinger, Michael Dillon and Matthew Simpson would like to express their gratitude to Mrs. Fernando Aluzzi and Robert Shectman for their assistance with the meteorological data, Drs. Michael Bradley, John Nasstrom, and Kevin Foster for their helpful review, and Drs. Bill Colston, Global Security Directorate Chem/Bio Division Leader, and Tom Bates, Threat Awareness Program Leader, for supporting this effort.

\subsection{References}

Beckett, S., Garner, M. (2007). Simulating disease spread within a geographic information system environment Veterinaria Italiana, 43 (3), 595-604.

D’Amours, R., and Malo, A. (2004). A Zeroth Order Lagrangian Particle Dispersion Model: MLDP0. Internal report, Canadian Meteorological Centre, Environmental Emergency Response Section, Dorval, Québec, Canada.

Donaldson, A. I. (1972). The influence of relative humidity on the aerosol stability of different strains of FMDV suspended in saliva. Journal of General Virology 15, 25 $-33$.

Donaldson, A. I., Ferris, N. P. (1974). The survival of FMDV in open air conditions. Journal of Hygiene, Cambridge 74, 409 - 416.

Draxler R.R. and Hess G.D. (1998) An overview of the HYSPLIT_4 modelling system for trajectories, dispersion and deposition, Australian Meteorological. Magazine, 47, 295-308.

Dubé, C., Stevenson, M. A., Garner, M. G., Sanson, R.L., Corso, B. A.., Harvey, N., Griffin, J., Wilesmith, J. W., Estrada, C. (2007) A comparison of predictions made by three simulation models of foot-and-mouth disease. New Zealand Veterinary Journal, 55(6), 280-288. 
Flesch, T., Wilson J., Crenna, B. (2002). MLCD: A Short-Range Atmospheric Dispersion Model for Emergency Response, Department of Earth and Atmospheric Sciences, University of Alberta, Edmonton. Internal report, Canadian Meteorological Centre, Environmental Emergency Response Section, Dorval, Québec, Canada.

Garner, M., Beckett, S. (2005). Modelling the spread of foot-and-mouth disease in Australia. Australian Veterinary Journal. 83, 30 - 38.

Garner M.G.,. Hess G. D, Yang X. (2005) An integrated modelling approach to assess the risk of wind-borne spread of foot-and-mouth disease virus from infected premises, Environmental Modelling and Assessment, 11, 195-207.

Gloster, J., Blackall, J., Sellers, R. F., Donaldson, A. I. (1981). Forecasting the spread of foot-and-mouth disease. Veterinary Record 108, 370-374.

Gloster, J., Ryan, E., Wright, C., Doel, C., Parida, S., Cox, S., Barnett, P., Schley, D., Gubbins, S., Paton, D. Review: Foot-and-disease virus: How much airborne virus do animals exhale? (Submitted to Veterinary Journal).

Grell, G. A., and D. Dèvènyi (2002). A generalized approach to parameterizing convection combining ensemble and data assimilation techniques, Geophysical. Research. Letters , 29, 38-1-38-4.

Hess G. D., Garner M.G. and X. Yang X. (2008). A sensitivity analysis of an integrated modelling approach to assess the risk of wind-borne spread of foot-andmouth disease virus from infected premises. Environmental Modelling and Assessment 13, 209-220.

Jones, A., Thomson, D., Hort, M., Devenish, B. (2007). The U.K. Met Office's nextgeneration atmospheric dispersion model, NAME III. In Air Pollution Modeling and its Application XVII, Borrego, C. and A-L. Norman(Eds.), Springer, 580-589.

Kalnay E., Kanamitsu, M., Kistler, Collins, W., Deaven, D., Gandin, L., Iredell, M., Saha, S., White, G., Woollen, J., Zhu, Y., Leetmaa, A., Reynolds, R., Chelliah, M., Ebisuzaki, W. Higgins, W., Janowiak, J., Mo, K.C., Ropelewski, C., Wang, J., Jenne, R. and Joseph, D. (1996). The NCEP/NCAR 40-Year Reanalysis Project. Bulletin. American. Meteorological. Society. 77, 437-471. 
Leone Jr., J.M., Nasstrom, J.S., Maddix, D.M., Larson, D.J., Sugiyama, G. and Ermak, D.L. (2005). Lagrangian Operational Dispersion Integrator (LODI) User's Guide, Report UCRL-AM-212798, Lawrence Livermore National Laboratory, Livermore, CA.

Mikkelsen, T., Thykier-Nielsen, S. Astrup, .P., Santabárbara, J. M., Sørensen, J. H., Rasmussen, A., Robertson, L., Ullerstig, A., Deme, S., Martens, R., Bartzis, J. G., Päsler-Sauer, J. (1997) MET-RODOS: A Comprehensive Atmospheric Dispersion Module. Radiation Protection Dosimetry 73, 45-56.

Nasstrom, J.S., Sugiyama, G., Baskett, R. L., Larsen, S. C., and Bradley, M. M. (2007) The National Atmospheric Release Advisory Center modelling and decision-support system for radiological and nuclear emergency preparedness and response. International Journal of Emergency Management. 4 (3), 524-550.

Sanson, R. (1993) The development of a decision support systemfor an animal disease emergency. Unpublished PhD Thesis. Massey University, Palmerston North, New Zealand.

Schley, D., Burgin, L., Gloster, J. Predicting infection risk of airborne Foot-andMouth Disease (accepted for publication by Interface, Journal of the Royal Society).

Schoenbaum, M., Disney, W. (2003). Modelling alternative mitigation strategies for a hypothetical outbreak of foot-and-mouth disease in the United States. Preventative Veterinay Medicine. 58, $25-52$.

Scire, J., Robe, F., Fernau, M. and Yamartino, R. (2000a). A User's Guide for the CALMET Meteorological Model (Version 5), Earth Tech Inc., Concord, MA.

Scire, J.S., Strimaitis, D.G. and Yamartino, R.J. (2000b). A user's guide for the CALPUFF dispersion model (Version 5), Earth Tech Inc., Concord, MA.

Sellers, R. F., Forman, A. J. (1973). The Hampshire epidemic of foot-and-mouth disease, 1967. Journal of Hygiene. Cambridge, 71, 15 - 34.

Sellers, R. F., Gloster, J. (2008). Foot-and-mouth disease: a review of intranasal infection of cattle, sheep and pigs. Veterinary Journal. 177, 159- 168. 
Skamarock, W. C., Klemp, J.B., Dudhia, J., Gill, D.O., Barker, D.M., Wang, W., Powers, J.G. (2005). A Description of the Advanced Research WRF Version 2. NCAR Technical Note: NCAR/TN-468+STR.

Sørensen, J. H.,. Alexandersen, S., Astrup, P., Christensen, K.E., Mikkelsen, T., Mortensen, S., Pedersen, T. S., Thykier-Nielsen, S. (2007). The VetMet veterinary decision support system for airborne animal diseases. Proceedings of the 29th NATO/SPS International Technical Meeting on Air Pollution Modelling and its Application, 24-28 September 2007a, Aveiro, Portugal.

Sørensen, J. H., Jensen, C. Ø. (1996) A Computer System for Management of Epidemiological Data and Prediction of Risk and Economic Consequences During Outbreaks of Foot-and-Mouth Disease. DMI Scientific Report 96-7 (1996) ISBN 87-7478-345-9, ISSN 0905-3263.

Sørensen J. H., Mackay D. K. J., Jensen C. Ø., Donaldson A. I (2000). An integrated model to predict the atmospheric spread of foot-and-mouth disease virus, Epidemiology and Infection. 124, $577-590$.

Sørensen, J. H., C. Ø. Jensen, T. Mikkelsen, D. Mackay and A. I. Donaldson. Modelling the atmospheric spread of foot-and-mouth disease virus for emergency preparedness. Physics Chemistry Earth 26 (2001) 93-97.

Stevenson, M., Morris, R.,Wilesmith, J., Stern, M. (2003). Predicting when and where foot-and-mouth disease will occur - how well did Interspread perform in 2001? In Proceedings of $10^{\text {th }}$ Symposium of the International Society for Veterinary Epidemiology and Economics, Vina Del Mar, Chile:ISVEE 10, 343.

Turner, R., Clarkson, T. (2006). Saleyard airborne risk profile. NIWA client report for New Zealand Ministry of Agriculture and Forestry, WLG2006-37. 114 pages.

Van Dop, H., Addis, R., Fraser, G, Girardi, F., Graziani, G., Inoue, Y., Kelly, N., Klug, W., Kulmala, A., Nodop, K, Pretel, J. (1998). ETEX A European tracer experiment; observations, dispersion modelling and emergency response. Atmospheric Environment, 32, 24, 4089 - 4094. 


\section{Captions for Figures}

Figure 1. Location of infected premises in the order they were confirmed.

9 = Fareham Abatoir; No.14 outside of the plotted area. TI = Thorney Island meteorological station; shaded area $=$ Portsdown Hill (ground above 200 feet).

Figure 2. Thorney Island wind analysis. Red $=>10 \mathrm{kts}$; Yellow $=5-10 \mathrm{kts}$; Green 1 $-5 \mathrm{kts}$; clear $=<1 \mathrm{kt}$.

Figure 3. PDEMS model output for the period 3 to 9 January. Red = area at greatest risk, white $=$ lowest area at risk. Crosses indicate location of infected premises.

Figure 4. 24-hour time integrated concentrations from all models for 9 January, using identical virus emission data.

Figure 5. Total accumulated dosages from all models for 29 December to 9 January, using identical virus emission data. 
Version 1.0 Submitted to Veterinary Journal

Input from LB, RS, MD, PH, RA, JS

3 September 2008

Table 1. Standard emission scenario. Units TCID $_{50} / 24 \mathrm{hrs}$

\section{January}

\begin{tabular}{|c|c|c|c|c|c|c|c|c|c|}
\hline $\mathbf{3 1} / \mathbf{1 2}$ & $\mathbf{1} / \mathbf{1}$ & $\mathbf{2 / 1} /$ & $\mathbf{3 / 1}$ & $\mathbf{4 / 1}$ & $\mathbf{5 / 1}$ & $\mathbf{6 / 1}$ & $\mathbf{7 / 1}$ & $\mathbf{8} / \mathbf{1}$ & $\mathbf{9 / 1}$ \\
\hline $1.9 \times 10^{5}$ & $3.6 \times 10^{5}$ & $7.4 \times 10^{5}$ & - & - & - & $1.3 \times 10^{5}$ & $2.8 \times 10^{5}$ & $3.4 \times 10^{5}$ & $1.1 \times 10^{5}$ \\
& & & & & & & & & \\
\hline
\end{tabular}


Table 2. Initial emission profiles ( $\left.\mathrm{TCID}_{50} / 24 \mathrm{hrs}\right)$ adopted by modellers

(a) Per pig as a function of clinical signs of disease

(based on published data)

\begin{tabular}{|l|l|c|c|c|c|c|c|}
\hline Model & Country & D-1* & D1 & D2 & D3 & D4 & D5 \\
\hline NAME $^{* *}$ & UK & & $1 \times 10^{6}$ & $5 \times 10^{5}$ & $3 \times 10^{4}$ & $3 \times 10^{4}$ & \\
\hline VetMet & Denmark & $6 \times 10^{1}$ & $1 \times 10^{6}$ & $1 \times 10^{6}$ & $5 \times 10^{4}$ & $8 \times 10^{2}$ & \\
\hline AIWM & Australia & & $3 \times 10^{5}$ & $6 \times 10^{5}$ & $6 \times 10^{5}$ & $5 \times 10^{5}$ & $4 \times 10^{5}$ \\
\hline PDEMS & New Zealand & $1 \times 10^{3}$ & $1 \times 10^{7}$ & $1 \times 10^{7}$ & $1 \times 10^{4}$ & $1 \times 10^{4}$ & \\
\hline MLCD & Canada & NA & NA & NA & NA & NA & NA \\
\hline NARAC & USA & $2 \times 10^{3}$ & $1 \times 10^{6}$ & $1 \times 10^{6}$ & $5 \times 10^{5}$ & $2 \times 10^{4}$ & \\
\hline
\end{tabular}

Notes:

* D1 the day that first clinical signs are observed; on the day before (D-1) the animals would appear healthy on clinical examination.

** Due to uncertain emission scenario UK modellers assumed a standard emission rate of $8 \times 10^{5} \mathrm{TCID}_{50} / 24 \mathrm{hrs}$ for the period $29 / 12$ to $9 / 1$ and also a best estimate based on observed clinical lesions found by examination of the pigs at the Abattoir.

NA Data not available at the initial workshop. (b) Total daily emission from Fareham Abattoir 3 to 9 January (data from (a) $x$ numbers of pigs assumed to be emitting virus)

\begin{tabular}{|c|c|c|c|c|c|c|}
\hline $\mathbf{3 / 1}$ & $\mathbf{4} / \mathbf{1}$ & $\mathbf{5 / 1}$ & $\mathbf{6 / 1}$ & $\mathbf{7 / 1}$ & $\mathbf{8} / \mathbf{1}$ & $\mathbf{9 / 1}$ \\
\hline $8 \times 10^{5}$ & $8 \times 10^{5}$ & $8 \times 10^{5}$ & $8 \times 10^{5}$ & $8 \times 10^{5}$ & $8 \times 10^{5}$ & $8 \times 10^{5}$ \\
& & & $3 \times 10^{6}$ & $6 \times 10^{6}$ & $7 \times 10^{6}$ & $2 \times 10^{6}$ \\
\hline & & $1 \times 10^{2}$ & $3 \times 10^{6}$ & $8 \times 10^{6}$ & $1 \times 10^{7}$ & $5 \times 10^{6}$ \\
\hline & $6 \times 10^{5}$ & $2 \times 10^{6}$ & $5 \times 10^{6}$ & $6 \times 10^{6}$ & $5 \times 10^{6}$ & $4 \times 10^{6}$ \\
\hline $1 \times 10^{7}$ & $1 \times 10^{7}$ & $2 \times 10^{7}$ & $7 \times 10^{7}$ & $9 \times 10^{7}$ & $4 \times 10^{7}$ & $1 \times 10^{8}$ \\
\hline $\mathrm{NA}$ & $\mathrm{NA}$ & $\mathrm{NA}$ & $\mathrm{NA}$ & $\mathrm{NA}$ & $\mathrm{NA}$ & $\mathrm{NA}$ \\
\hline & & $4 \times 10^{3}$ & $2 \times 10^{6}$ & $7 \times 10^{6}$ & $1 \times 10^{7}$ & $7 \times 10^{6}$ \\
\hline
\end{tabular}


Table 3. The total 24 hour integrated concentrations along the major axis of the plume at 1, 5, 10, $15 \mathrm{~km}$ and $20 \mathrm{~km}$ for $9 \mathrm{January}$.

\begin{tabular}{|l|l|c|c|c|c|c|}
\hline \multicolumn{1}{|c|}{ Model } & Country & $\mathbf{1 ~ k m}$ & $\mathbf{5 ~ k m}$ & $\mathbf{1 0} \mathbf{~ k m}$ & $\mathbf{1 5} \mathbf{~ k m}$ & $\mathbf{2 0} \mathbf{~ k m}$ \\
\hline NAME & UK & $1 \times 10^{-4}$ & $1 \times 10^{-5}$ & $8 \times 10^{-6}$ & $6 \times 10^{-6}$ & $3 \times 10^{-6}$ \\
\hline VetMet & Denmark & $3 \times 10^{-4}$ & $4 \times 10^{-5}$ & $8 \times 10^{-5}$ & $3 \times 10^{-6}$ & $2 \times 10^{-6}$ \\
\hline AIWM & Australia & NA & NA & NA & NA & NA \\
\hline PDEMS & New Zealand & $4 \times 10^{-5}$ & $4 \times 10^{-4}$ & $1 \times 10^{-5}$ & $6 \times 10^{-6}$ & $2 \times 10^{-6}$ \\
\hline MLCD & Canada & $1 \times 10^{-4}$ & $6 \times 10^{-6}$ & $2 \times 10^{-6}$ & $6 \times 10^{-7}$ & $5 \times 10^{-7}$ \\
\hline NARAC & USA & $2 \times 10^{-4}$ & $1 \times 10^{-5}$ & $4 \times 10^{-6}$ & $2 \times 10^{-6}$ & $1 \times 10^{-6}$ \\
\hline
\end{tabular}

NA - Not yet available 
Table 4. Outbreaks suggested by Sellers and Forman (1973) as being potentially infected by airborne virus emitted from Fareham Abattoir and model performance using the standard virus emission profile for the period 29 December to 9 January.

\begin{tabular}{|c|c|c|c|c|c|c|c|c|c|c|c|c|}
\hline \multirow[t]{2}{*}{ Model } & \multicolumn{12}{|c|}{ Outbreak no. (Distance in km from outbreak no. 9) } \\
\hline & $23(0.3)$ & $22(0.6)$ & $21(1.1)$ & $3(1.5)$ & $26(1.8)$ & $7(2.4)$ & $19(3.6)$ & $25(4.3)$ & $8(4.5)$ & $10(5.8)$ & $1(8.5)$ & $12(9.8)$ \\
\hline NAME & $\overline{\mathrm{H}}$ & $\mathrm{H}$ & $\mathrm{H}$ & $\mathrm{H}$ & $\mathrm{H}$ & $\mathrm{H}$ & $\bar{M}$ & $\mathrm{~L}$ & $\bar{M}$ & $\mathrm{M}$ & $\bar{M}$ & $\bar{M}$ \\
\hline VetMet & $\mathrm{H}$ & $\mathrm{M}$ & M & $\mathrm{M}$ & M & $\mathrm{M}$ & $\mathrm{L}$ & - & $\mathrm{L}$ & $\mathrm{L}$ & $\mathrm{L}$ & $\mathrm{L}$ \\
\hline PDEMS & $\mathrm{H}$ & $\mathrm{H}$ & $\mathrm{H}$ & $\mathrm{M}$ & M & M & $\mathrm{L}$ & $\mathrm{L}$ & M & $\mathrm{L}$ & $\mathrm{L}$ & $\mathrm{L}$ \\
\hline AIWM & $\mathrm{H}$ & $\mathrm{H}$ & $\mathrm{H}$ & $\mathrm{H}$ & $\mathrm{M}$ & $\mathrm{H}$ & $\mathrm{M}$ & $\mathrm{M}$ & $\mathrm{M}$ & $\mathrm{M}$ & $\mathrm{M}$ & $\mathrm{M}$ \\
\hline MLCD & $\mathrm{H}$ & $\mathrm{H}$ & $\mathrm{H}$ & $\mathrm{H}$ & $\mathrm{H}$ & $\mathrm{H}$ & $\mathrm{M}$ & $\mathrm{M}$ & $\mathrm{H}$ & $\mathrm{M}$ & $\mathrm{L}$ & $\mathrm{M}$ \\
\hline NARAC & NA & NA & NA & NA & NA & NA & NA & NA & NA & NA & NA & NA \\
\hline
\end{tabular}

$\mathrm{H}=$ highest risk category/accumulated dosage contour provided by modellers.

$\mathrm{M}=$ second highest risk category

$\mathrm{L}=$ third highest risk category

$-=$ not at risk

$\mathrm{NA}=$ not yet available 
Version 1.0 Submitted to Veterinary Journal

Input from LB, RS, MD, PH, RA, JS

3 September 2008

This work performed under the auspices of the U.S. Department of Energy by Lawrence Livermore National Laboratory under Contract DEAC52-07NA27344. 